\title{
Polyphosphate performance for inhibiting corrosion of heat exchanger materials
}

\author{
A. Nikitasari,* Sundjono, G. Priyotomo and A. Royani \\ Research Center for Metallurgy and Material, Indonesian Institute of Sciences, Puspiptek \\ 470 Building, South Tangerang, 15313, Indonesia \\ *E-mail: arininikitasari89@gmail.com
}

\begin{abstract}
The inhibitive performance of polyphosphate on the corrosion of heat exchanger materials, i.e., carbon steel A192 and C1015, in ammonia plant was explored. This research analyzed the inhibitive performance of polyphosphate by comparing the corrosion rates $(C R)$ of heat exchanger materials treated with polyphosphate and those without polyphosphate. Three polyphosphate concentrations and three temperatures were used in this experiment: $75 \mathrm{ppm}$, $100 \mathrm{ppm}, 150 \mathrm{ppm}$, and $32^{\circ} \mathrm{C}, 37^{\circ} \mathrm{C}$ and $50^{\circ} \mathrm{C}$, respectively. This experiment was conducted using an exposure test at Kujang Ammonium Plant and a laboratory test at Research Center for Metallurgy and Material. The exposure test specimens were exposed in a corrosion chamber for 28 days, 56 days, 84 days and 140 days. Visual observations and weight loss measurements were performed to analyze the results of the exposure test. Furthermore, electrochemical tests were carried out at the laboratory. Based on the exposure test, carbon steel A192 has a lower corrosion rate than carbon steel C1015 at each time of exposure. In addition, the corrosion rates of carbon steel A192 and C1015 decreased since 56 days of the exposure test due to the formation of thicker corrosion products. The laboratory test indicated that the corrosion rates of carbon steel A192 and C1015 decreased in the presence of polyphosphate. This result revealed the effectiveness of polyphosphate for inhibiting corrosion of heat exchanger materials. The efficiency of polyphosphate boosts with concentration and diminishes with temperature.
\end{abstract}

Keywords: polyphosphate, A192 steel, C1015 steel, heat exchanger, ammonia plant.

Received: March 24, 2020. Published: June 9, 2020

doi: $\underline{10.17675 / 2305-6894-2020-9-2-22}$

\section{Introduction}

A heat exchanger is a vital equipment for heat transfer and gas cooling at an ammonia plant. However, corrosion of heat exchanger equipment is a particularly important issue in an ammonia plant. During operation, corrosion products are usually formed on the surfaces of the heat exchanger. These deposits reduce the heat transfer efficiency and endanger the lifespan of the heat exchanger [1].

Corrosion occurs on the heat exchanger of ammonia plant as a result of an electrochemical reaction between the metal and the moisture present in the atmosphere [2]. Moreover, inorganic scaling and fouling form a deposit on the heat exchanger surface that 
induces under-deposit corrosion attack and eventually causes failure of the heat exchanger material [3-6]. In order to protect the heat exchanger material against corrosion, a corrosion inhibitor is the best solution due to low cost and ease in injecting.

A corrosion inhibitor is an organic or inorganic compound that suppresses corrosion, regardless of which electrochemical reaction it affects [7]. Polyphosphate is a corrosion inhibitor that can slow down the cathodic reaction [8]. Polyphosphates consist of a phosphorus atom that links to its neighbors through two oxygen atoms. Owing to a higher phosphate content and also high chelate building potential with multivalent metal cations, polyphosphates have better inhibitive performance compared to other inhibitors. Furthermore, it has been found that polyphosphates have sufficient water solubility to supply corrosion inhibition $[9,10]$. Therefore, polyphosphate was chosen as the corrosion inhibitor for heat exchanger materials in this experiment.

Many research studies have been performed in recent years in relation with the use of polyphosphates for corrosion inhibition. Nevertheless, in-depth studies of polyphosphates for inhibiting corrosion of heat exchanger materials have been rarely discussed. The aim of the present work is to study the performance of polyphosphate for inhibiting corrosion of A192 and C1015 steels (heat exchanger materials). The concentration and temperature were also varied to observe their effect on the corrosion rate.

\section{Experimental details}

\subsection{Materials}

The materials used in the tests were carbon steels A192 and C1015 whose chemical compositions are shown in Table 1. According to the heat exchanger environment in Kujang Ammonia Plant, the shell side of the heat exchanger was exposed to feed water (corrosive medium) and its contents are displayed in Table 2.

The corrosion inhibitor was prepared using polyphosphate (p.a., Merck). The concentrations of polyphosphate in this experiment were $75 \mathrm{ppm}, 100 \mathrm{ppm}$ and $150 \mathrm{ppm}$. The polyphosphate weighed using an analytical scale and dissolved in feed water in a $1000 \mathrm{ml}$ volumetric flask.

Table 1. Chemical composition of heat exchanger materials.

\begin{tabular}{ccccccccccc}
\hline \multirow{2}{*}{ Sample } & \multicolumn{10}{c}{ Chemical composition, (\%) } \\
\cline { 2 - 11 } & $\mathbf{C}$ & $\mathbf{S i}$ & $\mathbf{M n}$ & $\mathbf{P}$ & $\mathbf{S}$ & $\mathbf{N i}$ & $\mathbf{C r}$ & $\mathbf{M o}$ & $\mathbf{A l}$ & $\mathbf{C u}$ \\
\hline $\mathrm{A} 192$ & 0.17989 & 0.23616 & 0.51519 & 0.00092 & 0.0203 & 0.07239 & 0.20573 & 0.04174 & 0.06928 & 0.07178 \\
$\mathrm{C} 1015$ & 0.17298 & 0.24139 & 0.51664 & 0.00092 & 0.0382 & 0.16836 & 0.05453 & 0.05280 & 0.03555 & 0.23134 \\
\hline
\end{tabular}


Table 2. Chemical analysis of feed water.

\begin{tabular}{ccc}
\hline Item & Unit & Feed water \\
\hline $\mathrm{pH}$ & - & 8.27 \\
Turbidity & $\mathrm{NTU}$ & 0.37 \\
Colour (Pt/Co) & - & 0 \\
Conductivity & $\mu \mathrm{mhos}$ & 260 \\
Dissolved solid & $\mathrm{ppm}$ & 158 \\
Calcium hardness & $\mathrm{ppm}, \mathrm{CaCO}_{3}$ & 47.84 \\
Total hardness & $\mathrm{ppm}, \mathrm{CaCO}_{3}$ & 64.48 \\
Total alkalinity & $\mathrm{ppm}, \mathrm{CaCO}_{3}$ & 77.04 \\
Bicarbonate & $\mathrm{ppm}$ & 93.99 \\
Total chlorine, $\mathrm{Cl} l_{2}$ & $\mathrm{ppm}$ & 0 \\
Chloride, $\mathrm{Cl}^{-}$ & $\mathrm{ppm}$ & 13.35 \\
Sulphate, $\mathrm{SO}_{4}^{2-}$ & $\mathrm{ppm}$ & 26.98 \\
Sodium, $\mathrm{Na}^{-}$ & $\mathrm{ppm}$ & 77.84 \\
Potassium, $\mathrm{K}$ & $\mathrm{ppm}$ & 18.46 \\
Total Iron, $\mathrm{Fe}$ & $\mathrm{ppm}$ & 0.21 \\
Silica, $\mathrm{SiO}_{2}$ & $\mathrm{ppm}$ & 14.10 \\
\hline
\end{tabular}

\subsection{Exposure test}

The exposure test was carried out using carbon steel A192 and C1015 coupons $(7 \mathrm{~cm} \times 4 \mathrm{~cm})$ in a corrosion chamber installed on the heat exchanger of Kujang Ammonia Plant. The position of the corrosion chamber is shown in Figure 1. Figure 2 displays the installation of the corrosion chamber in Kujang Ammonia Plant. There were five durations of the exposure test: 28 days, 56 days, 84 days, 112 days and 140 days. All the samples intended for 28 and 56 days of exposure were located at the bottom of the corrosion chamber while the samples for 84,112 and 140 days lied on the top of the corrosion chamber.

Prior to the test, the surface of samples was degreased with acetone and rinsed with absolute ethanol, then weighted to within $0.0001 \mathrm{~g}$. Subsequent to the test, the specimens were descaled, rinsed with water and absolute alcohol, dried in natural state, and weighted again [11]. The corrosion rate $(v)$ was calculated according to Equation 1.

$$
v=\left[(\text { weight loss }(\mathrm{mg})) /\left(\text { area }\left(\mathrm{cm}^{2}\right) \times \text { time }(\mathrm{s})\right)\right]
$$




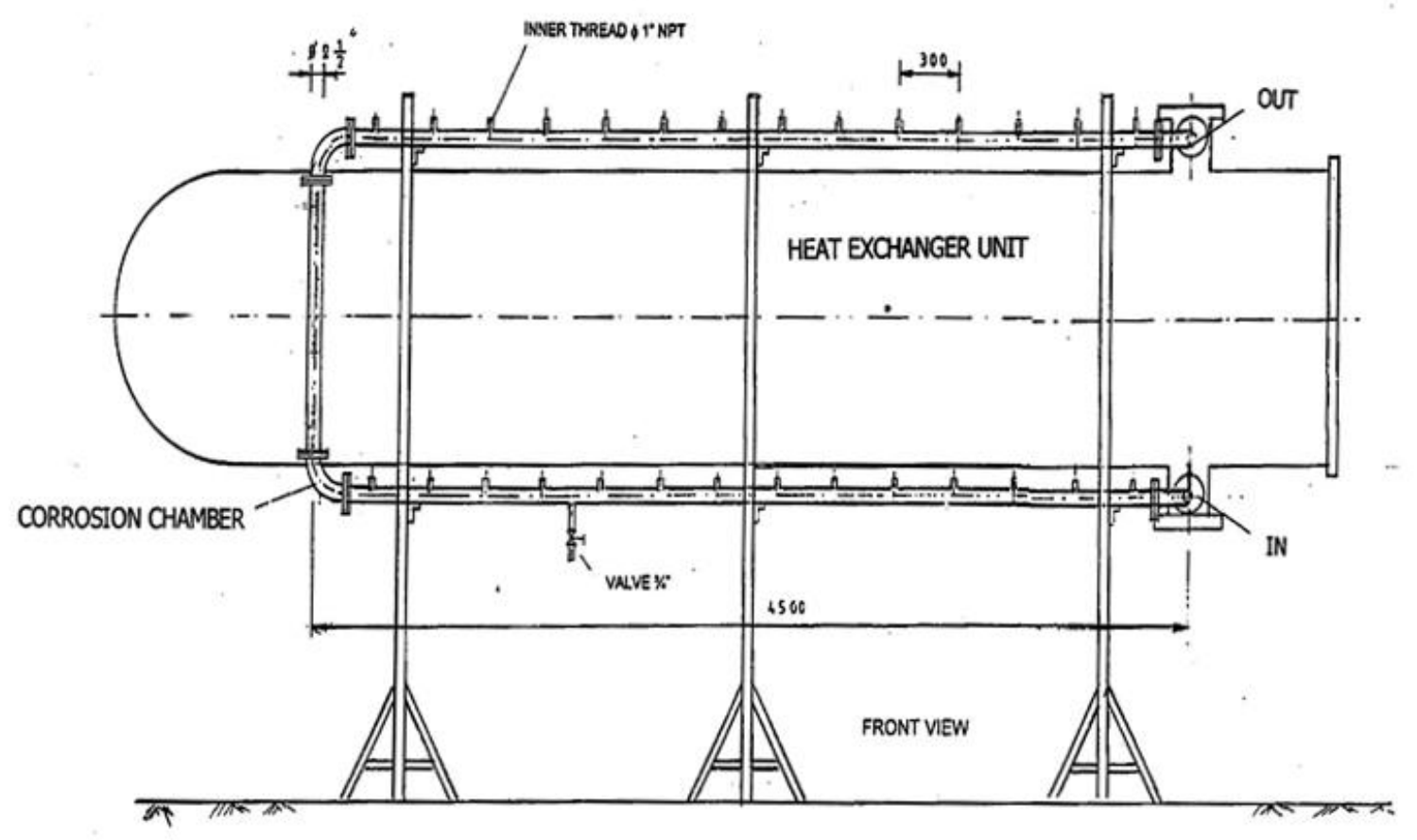

Figure 1. Position of corrosion chamber.

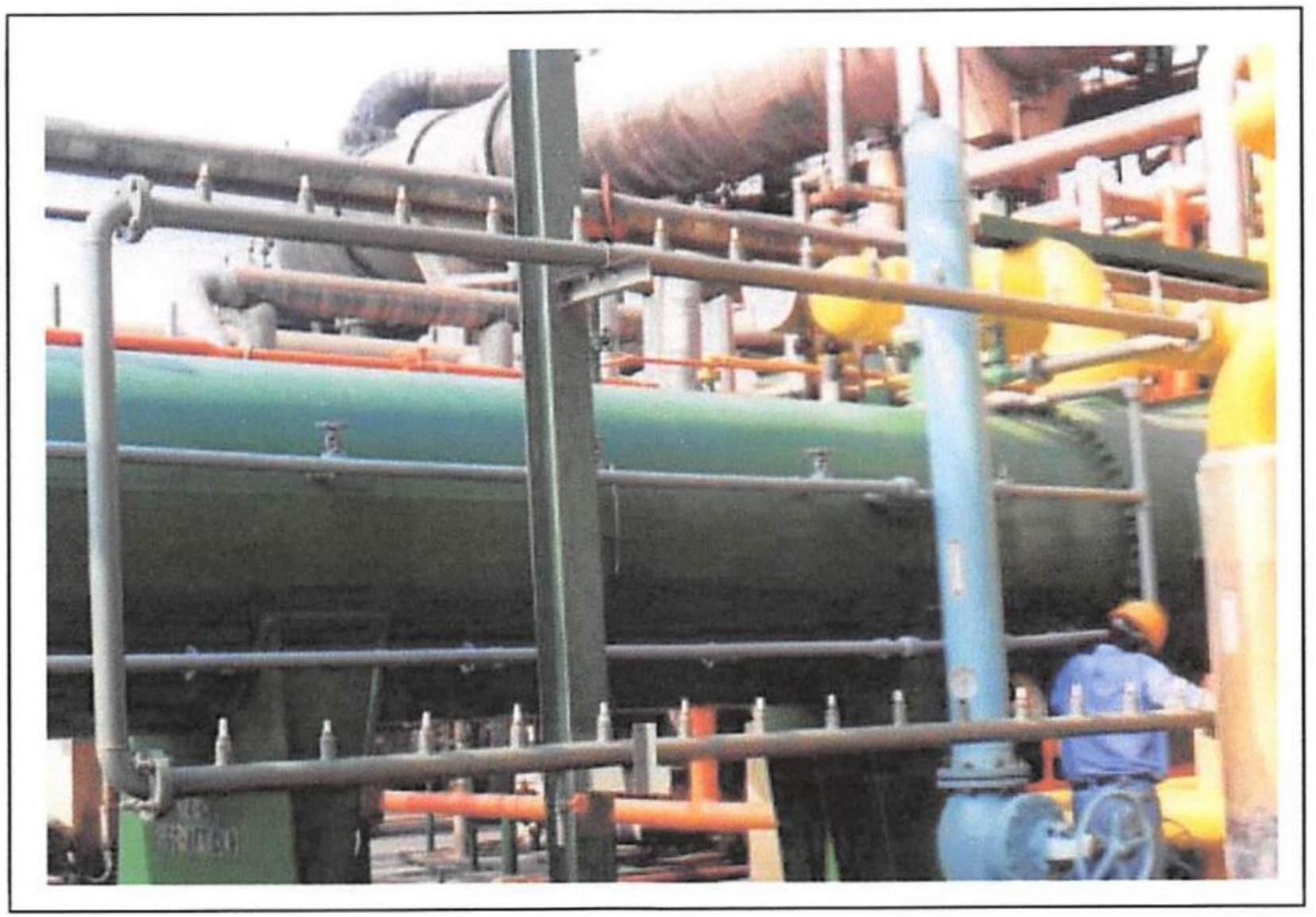

Figure 2. Installation of corrosion chamber. 


\subsection{Electrochemical test}

A Gamry instruments Series G750 device was used for the electrochemical test. Carbon steel A192 and C1015 were cut into size $(1 \mathrm{~cm} \times 1 \mathrm{~cm})$ to make samples for the electrochemical tests. In this corrosion measurement system, the samples were utilized as the working electrodes, a saturated calomel electrode (SCE) as the reference electrode, and $\mathrm{Pt}$ electrodes as counter electrodes. Feed water was used as a solution in this test. The temperature of the solution was varied at $32^{\circ} \mathrm{C}, 37^{\circ} \mathrm{C}$ and $50^{\circ} \mathrm{C}$. The electrochemical test was performed twice, in feed water solution without polyphosphate inhibitor and with addition of polyphosphate inhibitor.

\section{Result and discussion}

\subsection{Visual and weight loss analysis}

Visual observations were performed for corrosion monitoring in the exposure test. Figure 3-Figure 7 show visual observations of A192 and C1015 metal samples after the exposure test for 28,56,84,112 and 140 days, respectively. Based on the visual observation, the corrosion product is accumulated with time of exposure. There is more corrosion product on the C1015 surface than on the A192 surface according to visual observation results after the exposure test.

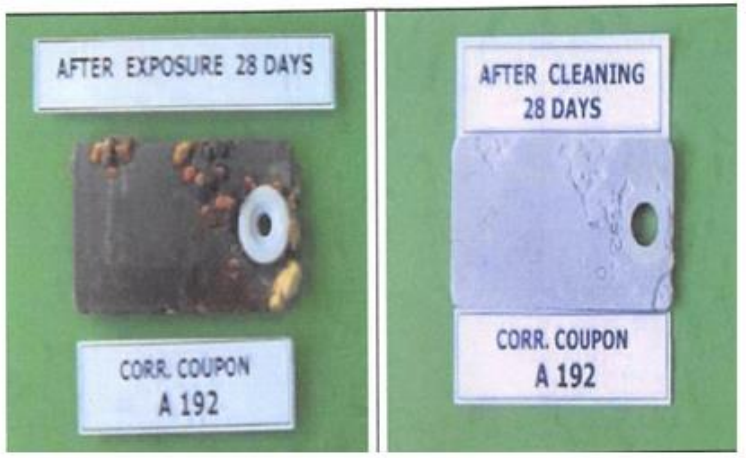

a

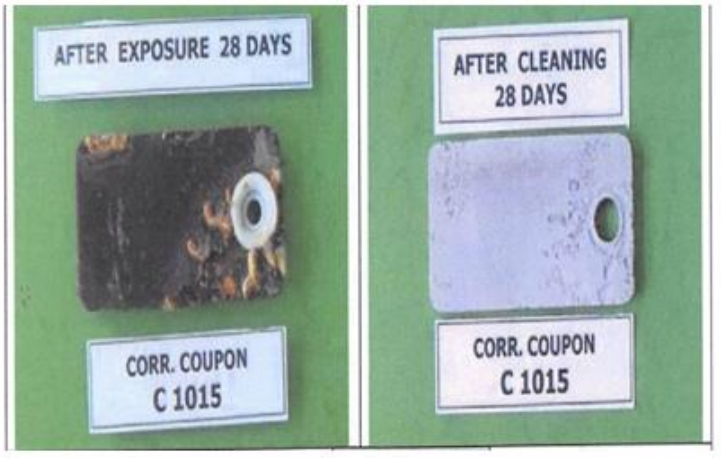

$\mathrm{b}$

Figure 3. Corrosion coupons of (a) A192 and (b) C1015 steels after exposure for 28 days.
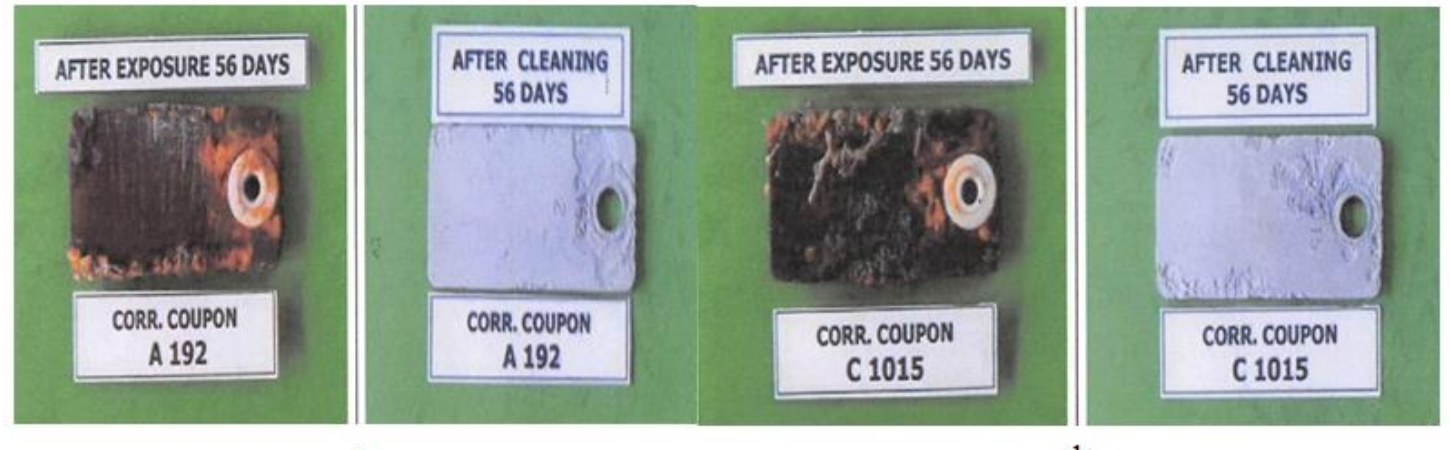

a

$\mathrm{b}$

Figure 4. Corrosion coupons of (a) A192 and (b) C1015 steels after exposure for 56 days. 


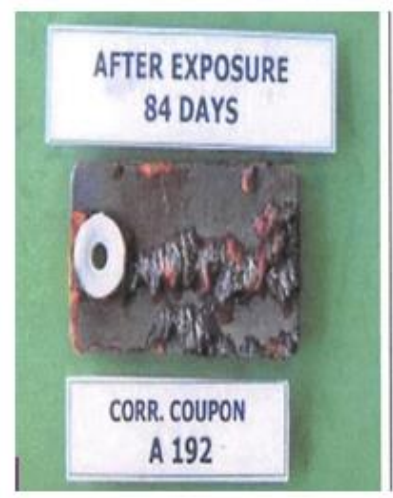

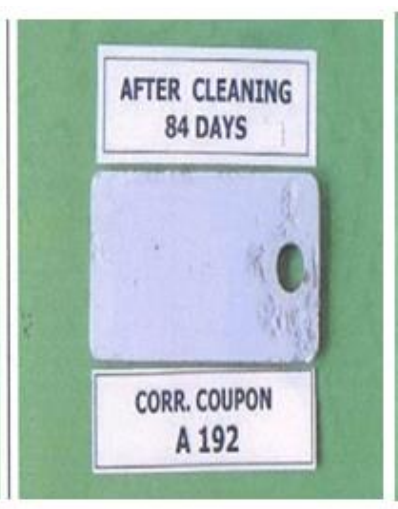

a
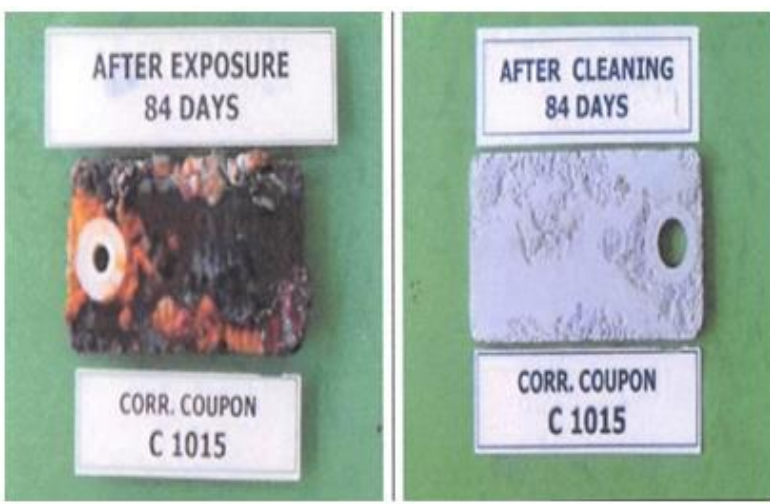

$\mathrm{b}$

Figure 5. Corrosion coupons of (a) A192 and (b) C1015 steels after exposure for 84 days.

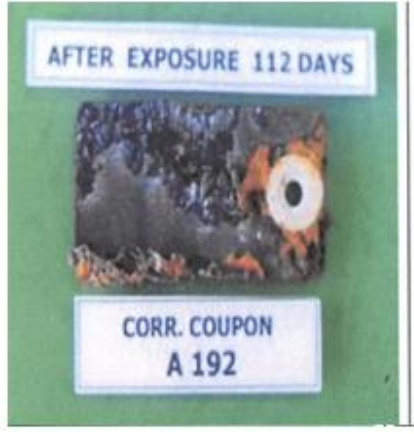

a

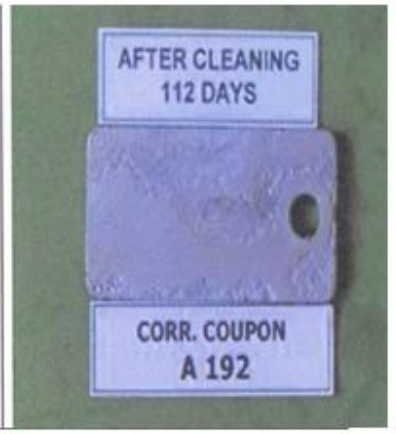

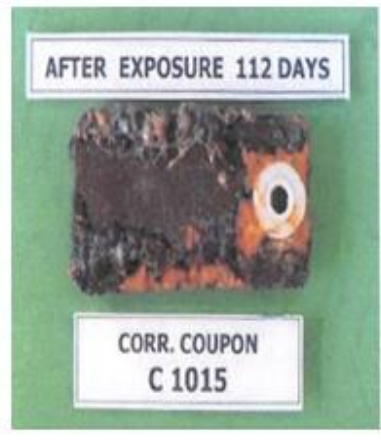

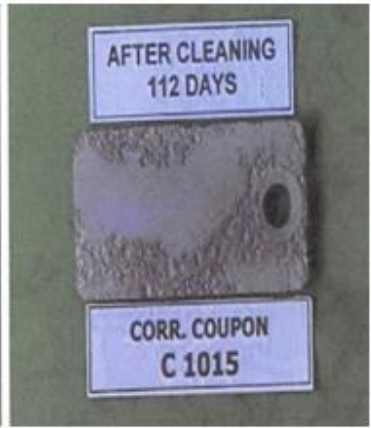

$\mathrm{b}$

Figure 6. Corrosion coupons of (a) A192 and (b) C1015 steels after exposure for 112 days.
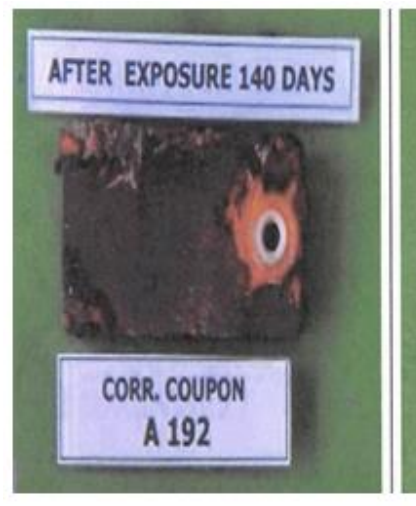

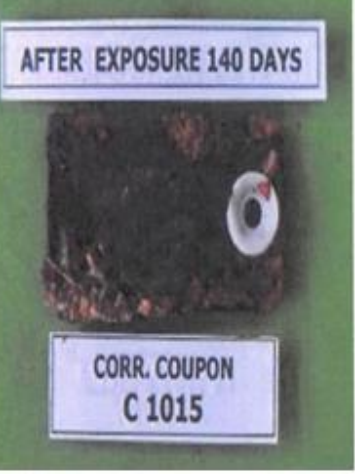

$\mathrm{b}$

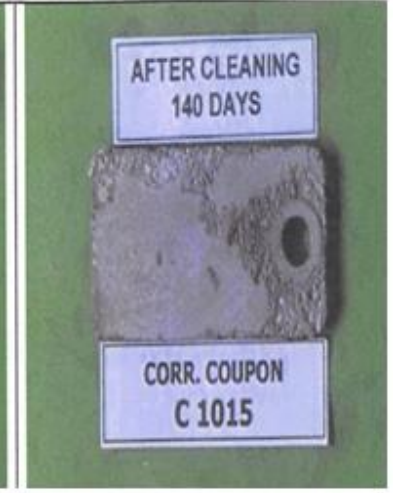

Figure 7. Corrosion coupons of (a) A192 and (b) C1015 steels after exposure for 140 days.

Table 3 lists the results of weight loss measurements. According to Table 3, the weight loss increases from 28 days to 56 days of exposure test, but from 84 days to 140 days, the weight loss decreases. The decrease in weight loss after exposure tests for more than 56 days is due to the thickness of the corrosion product. The corrosion product covers the metal surface and prevents contact between the metal and environment hence the corrosion rate decreases. 
Table 3. Weight loss measurements.

\begin{tabular}{ccccc}
\hline & \multicolumn{2}{c}{$\mathbf{A 1 9 2}$} & \multicolumn{2}{c}{ C1015 } \\
\cline { 2 - 5 } Days & $\begin{array}{c}\text { Weight loss, } \\
(\mathbf{m g})\end{array}$ & $\begin{array}{c}\text { Corrosion rate, } \\
(\mathbf{m p y})\end{array}$ & $\begin{array}{c}\text { Weight loss, } \\
(\mathbf{m g})\end{array}$ & $\begin{array}{c}\text { Corrosion rate, } \\
(\mathbf{m p y})\end{array}$ \\
\hline 28 & 472.5 & 10.84 & 610.7 & 13.97 \\
56 & 930.9 & 10.67 & 1323.7 & 15.15 \\
84 & 910.8 & 6.91 & 1536.4 & 11.63 \\
112 & 812.4 & 4.62 & 1908 & 10.83 \\
140 & 1002.9 & 4.56 & 1800.9 & 8.59 \\
\hline
\end{tabular}

\subsection{Influence of temperature on the corrosion rate of carbon steels A192 and C1015}

The influence of temperature on the corrosion rates $(C R)$ of A192 and C1015 steels was observed using an electrochemical test. Figures 8-10 present the test results of A192 and $\mathrm{C} 1015$ steels at temperatures of $32^{\circ} \mathrm{C}, 35^{\circ} \mathrm{C}$ and $50^{\circ} \mathrm{C}$, respectively. Based on Table 4 , C1015 steel has a higher $C R$ than A192 steel at each temperature. This result agrees with the visual and weight loss evidence. According to Table 1, the corrosion rate of A192 is smaller than that of $\mathrm{C} 1015$ because A192 has a higher chromium content.

The corrosion rates of A192 and C1015 increase with temperature. Higher temperatures can increase the $C R$ because the metals react faster at higher temperatures. Therefore, the highest corrosion rates of A192 and C1015 are observed at $50^{\circ} \mathrm{C}$.
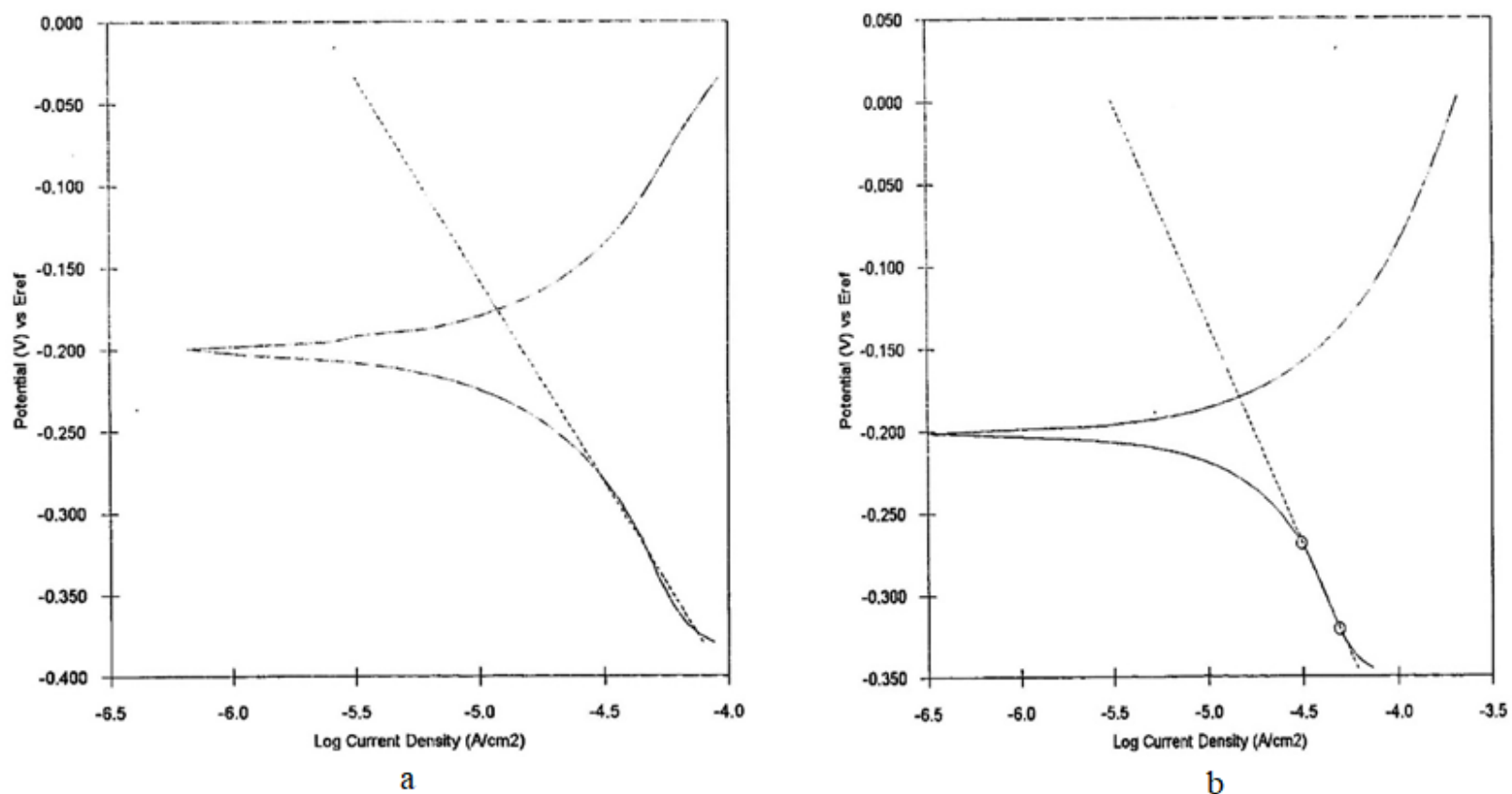

$\mathrm{b}$

Figure 8. Electrochemical curves of (a) A192 and (b) $\mathrm{C} 1015$ at $32^{\circ} \mathrm{C}$. 


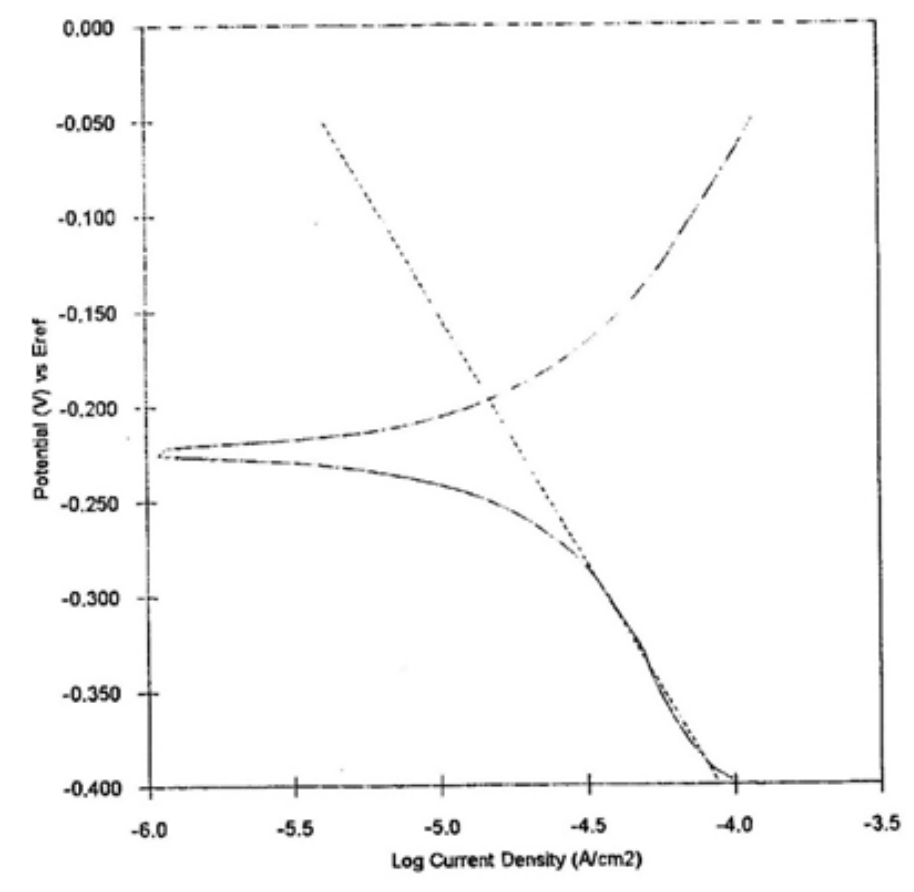

a

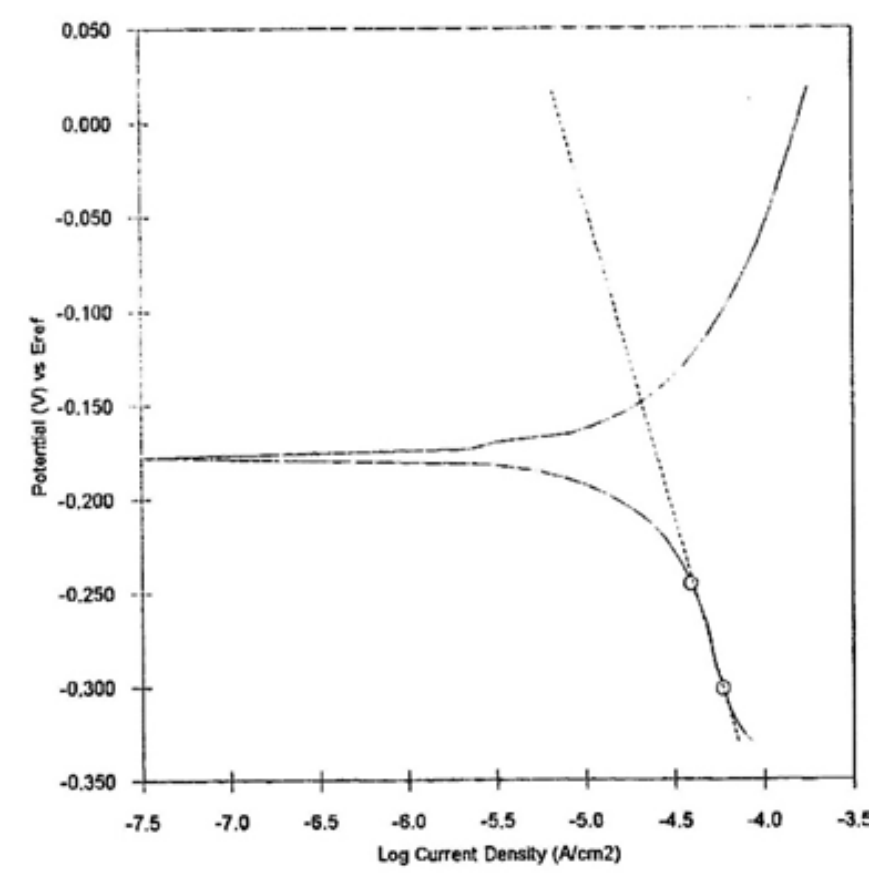

$\mathrm{b}$

Figure 9. Electrochemical curves of (a) A192 and (b) C1015 at $37^{\circ} \mathrm{C}$.
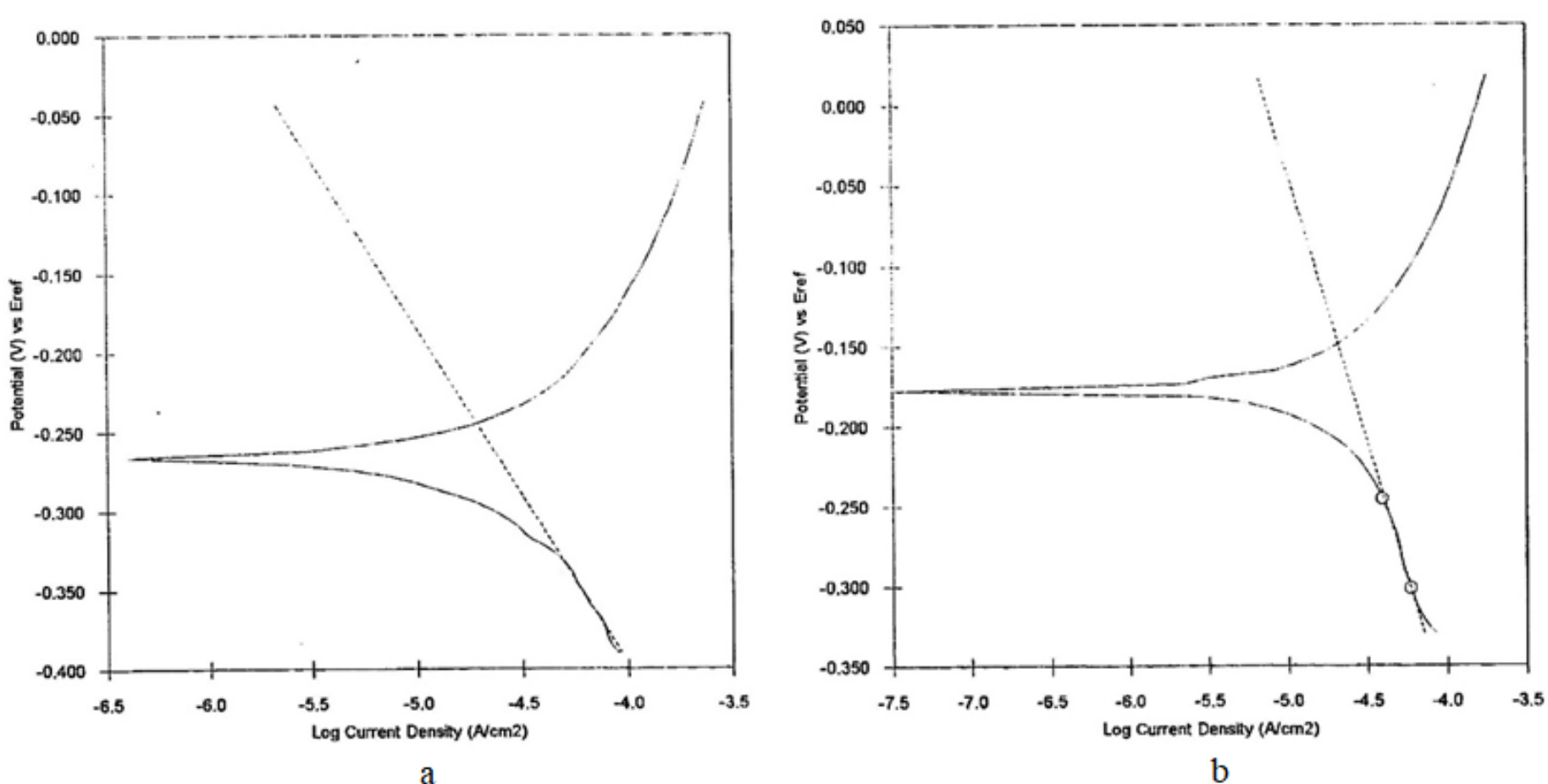

$\mathrm{b}$

Figure 10. Electrochemical curves of (a) A192 and (b) C1015 at $50^{\circ} \mathrm{C}$. 
Table 4. Corrosion rates based on electrochemical tests.

\begin{tabular}{cccc}
\hline \multirow{2}{*}{ Material } & \multicolumn{3}{c}{ Corrosion rate (mpy) } \\
\cline { 2 - 4 } & $\mathbf{3 2}^{\circ} \mathbf{C}$ & $\mathbf{3 7}^{\circ} \mathbf{C}$ & $\mathbf{5 0}^{\circ} \mathbf{C}$ \\
\hline $\mathrm{A} 192$ & 6.777 & 8.744 & 11.069 \\
$\mathrm{C} 1015$ & 8.071 & 11.554 & 13.949 \\
\hline
\end{tabular}

\subsection{Polyphosphate inhibitor efficiency}

The inhibitive performance of polyphosphate was analyzed using the difference in corrosion rates $(C R)$ obtained without and with polyphosphate addition. Polyphosphate was added at various concentrations to feed water to investigate the effect of concentration on the corrosion rate. The corrosion rate with polyphosphate addition was also obtained using the electrochemical test, along with the corrosion rate without polyphosphate addition. Figure 11(a) and 11(b) depict the corrosion rates of carbon steel A192 and C1015, respectively, with polyphosphate addition at various concentrations. Based on Figure 11, the corrosion rate increases with temperature and decreases with increasing polyphosphate concentration.

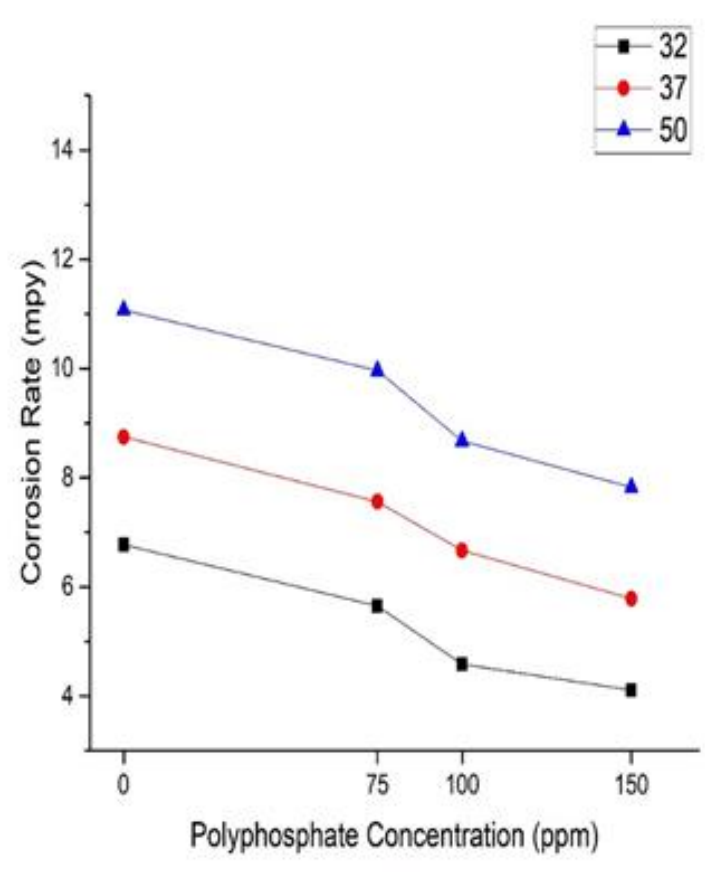

a

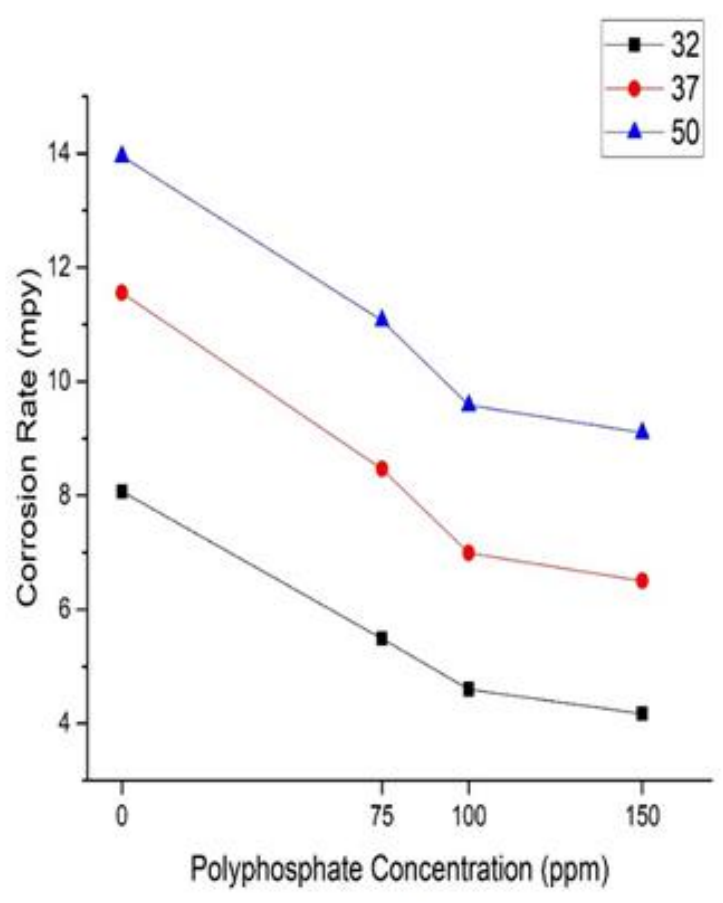

b

Figure 11. Corrosion rates of (a) A192 and (b) C1015 at various polyphosphate concentrations. 
Table 5. Polyphosphate efficiency.

\begin{tabular}{|c|c|c|c|c|c|c|c|}
\hline \multirow{3}{*}{ Material } & \multirow{3}{*}{$\begin{array}{l}\text { Polyphosphate } \\
\text { concentration } \\
\quad(\text { ppm })\end{array}$} & \multicolumn{6}{|c|}{ Temperature $\left({ }^{\circ} \mathbf{C}\right)$} \\
\hline & & \multicolumn{2}{|c|}{32} & \multicolumn{2}{|c|}{37} & \multicolumn{2}{|c|}{50} \\
\hline & & CR (mpy) & Eff $(\%)$ & $C R$ (mpy) & Eff $(\%)$ & $C R$ (mpy) & $\operatorname{Eff}(\%)$ \\
\hline \multirow{4}{*}{ A192 } & 0 & 6.770 & - & 8.744 & - & 11.067 & - \\
\hline & 75 & 5.653 & 16.50 & 7.561 & 13.53 & 9.962 & 9.98 \\
\hline & 100 & 4.582 & 32.32 & 6.666 & 23.76 & 8.671 & 21.65 \\
\hline & 150 & 4.108 & 39.32 & 5.786 & 33.83 & 7.825 & 29.29 \\
\hline \multirow{4}{*}{ C1015 } & 0 & 8.071 & - & 11.554 & - & 13.949 & - \\
\hline & 75 & 5.489 & 32.00 & 8.464 & 26.57 & 11.067 & 20.66 \\
\hline & 100 & 4.598 & 43.03 & 6.991 & 39.49 & 9.583 & 31.30 \\
\hline & 150 & 4.172 & 48.31 & 6.501 & 43.73 & 9.100 & 34.76 \\
\hline
\end{tabular}

Table 5 presents the efficiency of the polyphosphate inhibitor. The inhibitor efficiency was calculated by Equation 2 [12]. The percentage of polyphosphate efficiency boosts with concentration. This result indicates that polyphosphate has an ideal performance for inhibiting corrosion of heat exchanger materials (carbon steels A192 and C1015). Polyphosphate inhibits corrosion by dissolving in water and adsorbing on the metal surface, thereby hindering the access of hydrogen ions. The decrease in the flow of hydrogen ions to the metal surface will interfere with the hydrogen evolution reaction. Therefore, polyphosphate is classified as a cathodic inhibitor that interferes with the cathodic site of the electrochemical corrosion cell formation.

$$
\text { Inhibitor Efficiency }(\%)=\frac{C R_{\text {without inhibitor }}-C R_{\text {with inhibitor }}}{C R_{\text {without inhibitor }}} \cdot 100
$$

\section{Conclusion}

The corrosion rate of heat exchanger materials in the ammonia plant was determined by exposure and electrochemical tests. Based on the exposure and electrochemical tests, the corrosion rate of carbon steel A192 was lower than that of carbon steel C1015. Carbon steel A192 was found to be superior in corrosion resistance compared to carbon steel C1015 due to a higher chromium content. Polyphosphate inhibitor has good performance for inhibiting the corrosion of carbon steels A192 and C1015. Polyphosphate was able to reduce the corrosion rate by up to $40 \%$ at a concentration of $150 \mathrm{ppm}$ at $32^{\circ} \mathrm{C}$. The efficiency of polyphosphate boosts with concentration and diminishes with temperature. 


\section{Acknowledgements}

All authors contributed equally to this work. All authors discussed the results and implications and commented on the manuscript at all stages. The authors are grateful to Kujang Ammonia Plant for providing essential information and technical guidance that made this research possible. In addition, we would like to thank the Research Center for Metallurgy and Material, Indonesian Institute of Sciences, for the financial support.

\section{References}

1. I.B. Obot, A. Meroufel, I.B. Onyeachu, A. Alenazi and A.A. Sorour, Corrosion inhibitors for acid cleaning of desalination heat exchangers: Progress, challenges and future perspectives, J. Mol. Liq., 2019, 296, 111760. doi: 10.1016/j.molliq.2019.111760

2. P. Valeh-e-Sheyda and H. Rashidi, Inhibition of corrosion in amine air cooled heat exchanger: Experimental and numerical study, Appl. Therm. Eng., 2016, 98, 12411250. doi: 10.1016/j.applthermaleng.2015.12.101

3. T.K. Rout, N. Bandyopadhyay and T. Venugopalan, Polyphosphate coated steel sheet for superior corrosion resistance, Surf. Coat. Technol., 2006, 201, 1022-1030. doi: 10.1016/j.surfcoat.2006.01.027

4. S. Jingxin, M. Minyu, W. Tianjing, G. Xiaomei, H. Liguo and W. Zhiping, Fouling corrosion in aluminum heat exchangers, Chin. J. Aeronaut., 2015, 28, no. 3, 954-960. doi: $10.1016 /$ j.cja.2015.02.015

5. M.A. Deyab, Corrosion inhibition of heat exchanger tubing material (titanium) in MSF desalination plants in acid cleaning solution using aromatic nitro compounds, Desalination, 2018, 439, 73-79. doi: 10.1016/j.desal.2018.04.005

6. S.A.J. Jahromi, M.M. Alipour and A. Beirami, Failure analysis of 101-C ammonia plant heat exchanger, Eng. Failure Anal., 2003, 10, 405-421. doi: 10.1016/S1350$\underline{6307(03) 00016-5}$

7. M.H. Panjeshahi, E.G. Langeroudi and N. Tahouni, Heat and Power Optimization in Ammonia Plant, AIChE Annu. Meet., Conf. Proc., 2006.

8. K. Komalasari and Z. Zultiniar, Inhibitor Polifosfat Untuk Mengendalikan Korosi Pada Pipa Sistem Pendistribusian Air, February, 2016 (in Indonesian). doi: 10.31258/jst.v13.n1.p\%25p

9. R. Naderi and M.M. Attar, The inhibitive performance of polyphosphate-based anticorrosion pigments using electrochemical techniques, Dyes Pigm., 2009, 80, no. 3, 349-354. doi: 10.1016/j.dyepig.2008.08.002

10. M. Lebrini, F. Bentiss, N. Chihib, C. Jama, J. Pierre and M. Lagrenée, Polyphosphate derivatives of guanidine and urea copolymer: Inhibiting corrosion effect of Armco iron in acid solution and antibacterial activity, Corros. Sci., 2008, 50, no. 10, 2914-2918. doi: $\underline{10.1016 / j . c o r s c i .2008 .07 .003}$ 
11. X. Xiu-qing, B. Zhen-quan, F. Yao-rong, M. Qiu-rong and Z. Wen-zhen, The influence of temperature on the corrosion resistance of $10 \#$ carbon steel for refinery heat exchanger tubes, Appl. Surf. Sci., 2013, 280, no. 32, 641-645. doi: 10.1016/j.apsusc.2013.05.038

12. P.A. Jeeva, G.S. Mali, R. Dinakaran, K. Mohanam and S. Karthikeyan, The influence of Co-Amoxiclav on the corrosion inhibition of mild steel in $1 \mathrm{~N}$ hydrochloric acid solution, Int. J. Corros. Scale Inhib., 2019, 8, no. 1, 1-12. doi: 10.17675/2305-6894$\underline{2019-8-1-1}$ 